\title{
BIOMECHANICS OF SHOD AND BAREFOOT RUNNING: A LITERATURE REVIEW
}

\author{
BIOMECÂNICA DA CORRIDA COM CALÇADO EDESCALÇO:REVISÃO DA LITERATURA
}

BIOMECÁNICA DE LA CARRERA CON CALZADO Y DESCALZO: REVISÓN DE LA LITERATURA

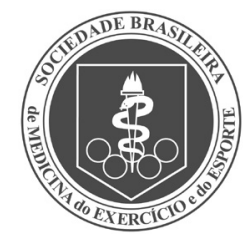

ReView Article

ARtIGo de REVISÃo ARtículo de REVISIÓN

\author{
Vitória da Silveira Jahn ${ }^{1}$ (ID \\ (Physical Education Professional) \\ Clara Knierim Correia' (D) \\ (Physical Education Professional) \\ Elisa Dell'Antonio' (DD \\ (Physical Education Professional) \\ Luis Mochizuki² iD \\ (Physical Education Professional) \\ Caroline Ruschel' (D) \\ (Physical Education Professional)
}

1. Universidade do Estado de Santa Catarina (UDESC), Center for Health and Sports Sciences (CEFID), Department of Physical Education, Aquatic Biomechanics Research Laboratory (BIOAQUA), Florianópolis, SC, Brazil. 2. Universidade de São Paulo (USP), School of Arts, Sciences and Humanities, São Paulo, SP, Brazil.

\section{Correspondence:}

Clara Knierim Correia.

Rua Pascoal Simone, 358.

Laboratório de Pesquisas em Biomecânica Aquática. Coqueiros, Florianópolis, SC, Brazil. CEP: 88080-350.

clara.kc@hotmail.com.

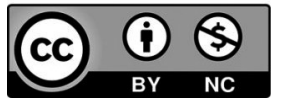

\section{ABSTRACT}

This study aims to analyze and summarize the biomechanical (kinematics, kinetics and neuromuscular) differences between shod and barefoot running, through a literature review. Searches were conducted for complete articles published between 2013 and November 2018 in the Web of Science, PubMed, Scopus and SPORTdiscus databases. The search terms used were Biomechanics, Kinetics, Kinematics, Electromyography, "Surface Electromyography"; and Unshod, Barefoot, Barefeet and Running. The search resulted in 687 articles; after excluding duplicates and selecting by title, abstract and full text, 40 articles were included in the review. The results show that there are important differences in the biomechanics of running when shod or barefoot. In general, studies indicate that in barefoot running: a) individuals present forefoot or midfoot foot strike patterns, while in shod running the typical pattern is the rearfoot strike; (b) greater cadence and shorter stride length are observed; and (c) there is greater knee flexion, lower peak vertical ground reaction force and greater activation of the medial gastrocnemius. In addition, barefoot runners contact the ground with greater plantar flexion, possibly as a strategy to reduce impact when stepping without footwear. These differences, as well as runners' individual characteristics, should be considered in the prescription of the barefoot running, in order to minimize injuries resulting from the practice. Level of Evidence Il; Review.

Keywords: Kinetics; Kinematics; Electromyography.

\section{RESUMO}

Este estudo tem como objetivo analisar e resumir as diferenças biomecânicas (cinéticas, cinemáticas e neuromusculares) da corrida com calçado e descalço através de uma revisão de literatura. Foram realizadas buscas por artigos completos publicados entre 2013 e novembro de 2018 nos bancos de dados Web of Science, PubMed, Scopus e SPORTDiscus. Os descritores usados foram Biomechanics, Kinetics, Kinematics, Electromyography, "Surface Electromyography"; e Unshod, Barefoot, Barefeet e Running. A busca resultou em 687 artigos, e depois da exclusão das duplicatas e seleção através do título, do resumo e do texto completo, 40 artigos foram incluídos na revisão. Os resultados evidenciam que existem diferenças importantes na biomecânica da corrida entre as condições calçado e descalço. De maneira geral, os estudos indicam que, na corrida descalço: (a) os indivíduos apresentam padrão de pisada com o antepé ou mesopé, enquanto na corrida com calçado, o padrão típico é com o retropé; (b) observa-se maior cadência e menor comprimento da passada; e (c) ocorre maior flexão de joelho, menor pico de força vertical de reação do solo e maior a tivação da parte medial do gastrocnêmio. Ainda, na condição descalço, os corredores fazem o contato com o solo com maior flexão plantar, possivelmente buscando uma estratégia de atenuação de impacto durante a pisada sem calçado. Essas diferenças, assim como a individualidade dos praticantes, devem ser consideradas na prescrição da corrida descalço, visando minimizar a ocorrência de lesões decorrentes da prática.

\section{Nível de evidência ll; Estudo de Revisão.}

Descritores: Cinética; Cinemática; Eletromiografia.

\section{RESUMEN}

Este estudio tiene como objetivo analizar y resumir las diferencias biomecánicas (cinéticas, cinemáticas y neuromusculares) de la carrera con calzado y descalzo a través de una revisión de literatura. Fueron realizadas búsquedas de artículos completos publicados entre 2013 y noviembre de 2018 en los bancos de datos Web of Science, PubMed, Scopus y SPORTDiscus. Los descriptores utilizados fueron Biomechanics, Kinetics, Kinematics, Electromyography, "Surface Electromyography"; y Unshod, Barefoot, Barefeet; y Running. La búsqueda resultó en 687 artículos, y después de la exclusión de los duplicados y selección a través del título, del resumen y del texto completo, 40 artículos fueron incluidos en la revisión. Los resultados evidencian que existen diferencias importantes en la biomecánica de la carrera entre las condiciones calzado y descalzo. De manera general, los estudios indican que, en la carrera descalzo: (a) los individuos presentan padrón de pisada con el antepié o mesopié, mientras que en la carrera con calzados, el padrón típico es con el retropié; (b) se observa mayor cadencia y menor longitud de la pasada; y (c) ocurre mayor flexión de la rodilla, menor pico de fuerza vertical de reacción del suelo y mayor activación de la parte medial del gastrocnemio. Además, en la condición descalzo, los corredores hacen el contacto con el suelo con mayor flexión plantar, posiblemente buscando una estrategia de atenuación de impacto durante 
la pisada sin calzado. Estas diferencias, así como la individualidad de los practicantes, deben ser consideradas en la prescripción de la carrera descalzo, buscando minimizar la ocurrencia de lesiones provenientes de la práctica.

Nivel de Evidencia Il; Estudio de Revisión.

Descriptores: Cinética; Cinemática; Electromiografía.

Article received on 02/07/2019 accepted on 07/20/2020

\section{INTRODUCTION}

Health benefits, low cost and improving coaching professionalization are some reasons to support road running popularity. In 2017, there were almost 20 million participants enrolled in road races in Brazil and in the United States of America. ${ }^{1,2}$ Along with such popularity, a high injury incidence ranging from 19.4\% to $79.3 \%$ was observed. ${ }^{3}$ Injury-related factors are improper running shoes, improper training and biomechanical factors. ${ }^{4}$ Therefore, to deal with running injuries, comfort and performance running shoes were developed ${ }_{1}^{5}$ while barefoot running became popular., ${ }^{6,7}$ Why did these two actions become popular in outdoor running?

Historically, neolithic man already wore rudimentary footwear and the athlete Abebe Bikila, running barefoot, won the marathon of the 1960 Olympic Games in Rome. Although wearing shoes is an established human habit, people still have nice performance running barefoot. Robbins and Gouw ${ }^{8}$ proposed the hypothesis modern sport shoes would be unable to protect individuals from running injuries because they attenuate plantar sensory information, which is necessary to change how they run. Two decades later, Liebermann et al. ${ }^{9}$ showed the transient ground reaction force (GRF) ${ }^{10}$ was absent in runners used to barefoot running. In this context, the discussion about running with shoes or barefoot is controversial. The sport's shoes technological development attracts consumers and, conversely, studies suggesting the barefoot running can eliminate the transient GRF pattern, leading to lower heel impact during running. ${ }^{9}$ For different reasons, also guided by the need to reduce the risk of injury, people run barefoot or with some type of footwear.

Hall et al. ${ }^{7}$ reviewed the biomechanical differences of running with and without shoes. How does footwear affect joint kinematics in running? Moderate evidence indicates running barefoot is associated with higher cadence and lower dorsiflexion at first foot contact with the ground. Limited evidence suggests the forefoot pattern is more common in barefoot running. Does GRF decrease in barefoot running? Hall et al. ${ }^{7}$ indicated the decreasing in peak GRF during barefoot running has moderate evidence. Different foot strike patterns modify how the foot first touches the ground and receives the impact and changes how foot muscles will attenuate such mechanical impact. ${ }^{11}$ Does running barefoot alter the muscle activation patterns? Only two studies, with limited evidence, describe how muscles act in running with shoes and barefoot.

All these issues continue to diverge opinions. Are new studies pointing out to the same direction as Hall et al. ${ }^{7}$ findings, concerning biomechanical comparisons between shod and barefoot running? Recent investigations indicate that are differences between these conditions in kinematics (spatiotemporal parameters or joint kinematics) ${ }^{12-14}$, kinetics (peak GRF and moments) ${ }^{15,16}$ and neuromuscular aspects ${ }^{11,17}$. Identifying these differences is important to minimize the injury risk, ${ }^{6}$ and they should be summarized to guide running practice. In this sense, the aim of the study was to analyze and summarize the biomechanical (kinematics, kinetics and neuromuscular) differences between barefoot and shod running, through a literature review.

\section{METHOD}

The literature search was performed on the Web of Science, PubMed, Scopus, and SportDiscus databases. The descriptors, Boolean operators and the search strategy are presented in table 1, clustered into biomechanical analysis, barefoot condition and running. Inclusion criteria were: complete research articles with biomechanical variables (kinematics, kinetics and/or neuromuscular aspects) comparing running with and without shoes, with persons older than 18 years old, with at least one group of healthy individuals. Only articles published in English between 2013 and 2018 in peer-reviewed journals were selected. Review studies, studies without full text available, and conference proceeding papers were excluded.

The literature search occurred in November 2018. We have only included studies from 2013 because another review about the same subject has already been published in that year ${ }^{7}$. Thus, this is an updated review about this topic.

For the literature synthesis, data about a) participants (sex, age, sample size, and level of experience in running); b) kinematics; and c) kinetics and d) neuromuscular results were presented. Only variables described for at least two studies and with statistically significant differences between shod and barefoot conditions were depicted.

Table 1 . Descriptors used in searches.

\begin{tabular}{c|c}
\hline Block \#1 & $\begin{array}{c}\text { (Biomechanics OR Kinetics OR Kinematics OR } \\
\text { Electromyography OR "Surface Electromyography") }\end{array}$ \\
\hline Block \#2 & (Unshod OR Barefoot OR Barefeet) \\
\hline Block \#3 & Running \\
\hline Used in searches: & Combination \#1 AND Combination \#2 AND \#3 combination \\
\hline
\end{tabular}

\section{RESULTS}

Six-hundred-eighty-seven studies were found, of these, 185 were duplicated, resulting in 502 studies to read the title. One-hundred-fifty-four papers were selected, and, after reading their abstract, 71 articles were chosen for full reading. Applying the eligibility criteria, 40 articles were included for the analysis, according to Figure 1.

Participants' characteristics are in Table 2. These participants were experienced in running, but rarely in barefoot running or wearing minimalist footwear. Twelve studies included rearfoot runners, while the others did not have foot strike pattern as inclusion criteria. Sample size ranged from six to 241 participants, from 18 to 55 years old. Regarding sex, 17 studies have included only males, one study included only females, and 22 studies included both sexes. Most studies have included amateur runners with varying weekly race volumes.

Methodological aspects of each study are summarized in Figure 2. In 19 studies, ${ }^{11,15,16,18-33}$ participants ran on instrumented track; in 18 studies, ${ }^{12-14,17,34-47}$ their participants had run on instrumented treadmill; while three ${ }^{48-50}$ did not inform where participants had run. Regarding running speed, in 21 studies $^{11,14-18,24,26,28,30-33,35,37,38,41-43,45,48}$ participants have run on a fixed speed, ranging from 8 to $14.4 \mathrm{~km} / \mathrm{h}$; in $14 \mathrm{stu}$ dies, $14,17,21-24,28,35,39,40,43,45,46,49$ participants ran in their self-selected speed, and the other five ${ }^{15,30,48-50}$ did not report the test running speed. 


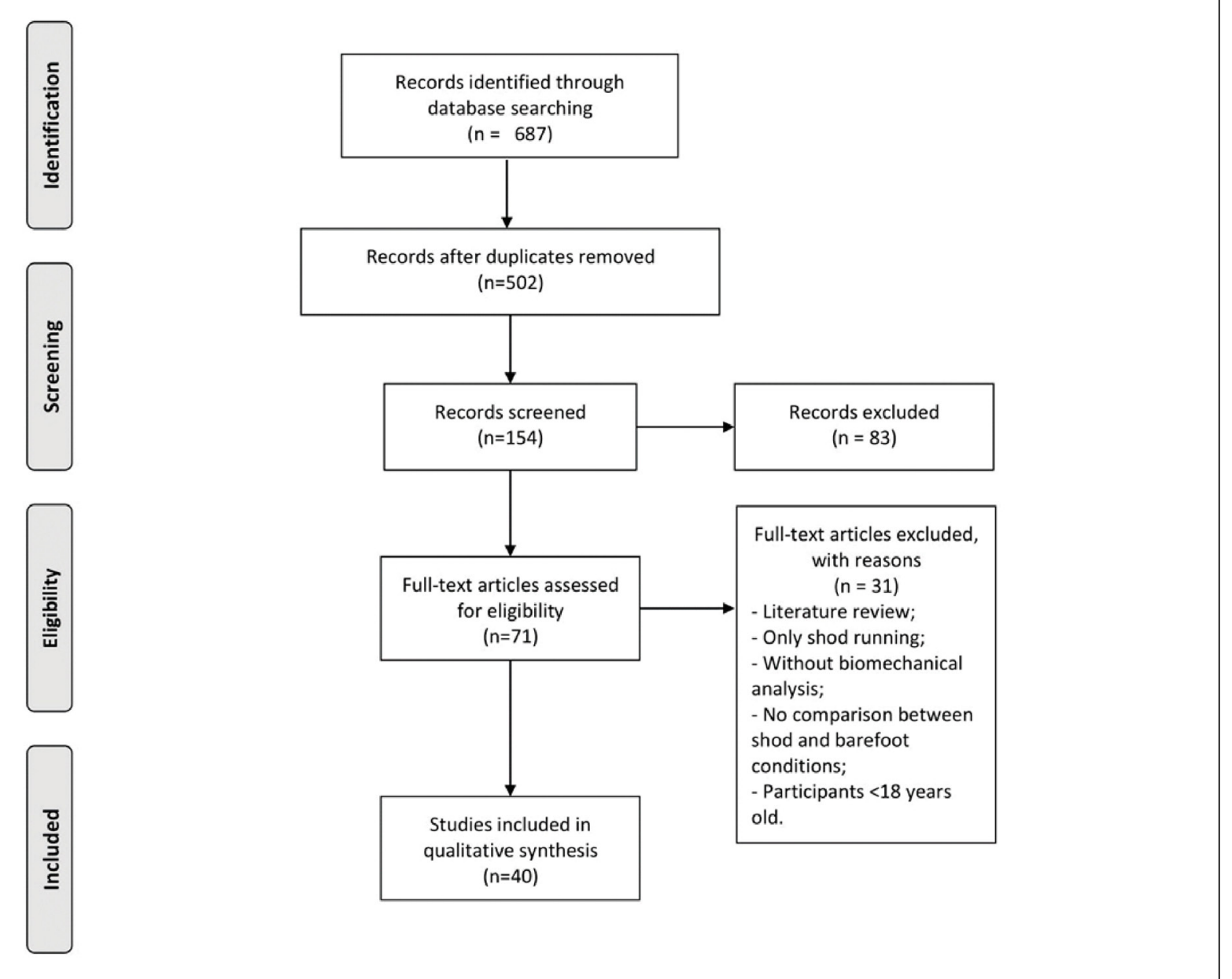

Figure 1. Flowchart of the studies' selection process.

The number of studies that showed significant differences for kinematic, kinetic and neuromuscular variables between shod and barefoot running are depicted in Figure 3. These studies compared barefoot and shod running, and some of them did also compare different footwear types/models..$^{14,43,44}$ One study ${ }^{41}$ tested running on different slopes, other two ${ }^{14,45}$ compared different running speeds and another ${ }^{16}$ compared different stride lengths.

\section{Kinematics}

Thirty-three studies analyzed the running kinematics (spatiotemporal parameters or joint kinematics) (Figures 3A and 3B). Considering spatiotemporal parameters, six studies ${ }^{30,31,36,41,42,45}$ showed runners usually hit the ground with the rearfoot when they were wearing shoes, and the other six $x^{17,30,31,36,43,45}$ showed their participants had hit the ground with the midfoot or forefoot whilst running barefoot. Shod running presented larger stride length, 12,13,15,17,22,24,25,27,28,31,43,44 longer stride time, , $^{14,36,47}$ Ionger contact time. $14,31,36,39,47$ Running barefoot presented higher caden ce $^{12-15,17,27,34,36,39,42,44,49}$ and longer flight time. ${ }^{39.49}$

Regarding ankle joint kinematics, most studies $(88 \%)^{12,13,15,20,22-}$ $24,2,29,31,32,37,41,44,50$ found shod running was associated with higher dorsiflexion, while six studies $13,15,20,27,43$ showed running barefoot involves greater plantar-flexion. Knee flexion is higher in shod running. 13,15,27,31,32,48 In most (67\%) of the six studies that analyze hip kinematics, $13,18,23,31$ runners used to shod running presented greater hip flexion.

The three-dimension motion analysis was applied to every study about ankle and knee kinematics. Running barefoot $18,27,34,37,40,50$ presented larger ankle range of motion (ROM) during stance phase. Regarding knee ROM, results are variable ${ }^{18,34,39,46}$ and only one study ${ }^{21}$ compared knee kinematics at different gait phases.

\section{Kinetics}

Fourteen studies measured any kinetic variables, such as external moment, impact, and loading rate (Figure 3C). Considering the GRF, most studies showed the loading rate is higher in barefoot condition, 20,28,31,34,47,48 and the impact peak has opposite results.22,24 Regarding articular moments, plantar flexion moment was higher in the barefoot condition, 15,16 while knee extension moment was higher in shod condition. ${ }^{15,33}$

\section{Neuromuscular aspects}

Seven studies analyzed neuromuscular aspects during running (Figure 3D). The tibialis anterior muscle has been more active during shod running. ${ }^{17,18,35,40}$ The triceps surae muscle usually $(72 \%)^{11,16,17,35,37}$ showed more activation in barefoot condition. For biceps femoris $^{34,40}$ and soleus ${ }^{11,40}$ muscles, results are divergent in the few studies found. Sinclair et al., ${ }^{18}$ using computational modeling, showed quadriceps muscle (rectus femoris, vastus medialis, and vastus lateralis muscles) and tibialis anterior muscle forces were higher during shod running, while gastrocnemius medialis muscle force was higher in barefoot running.

\section{DISCUSSION}

This study aimed to analyze and summarize the biomechanical (kinematics, kinetics and neuromuscular) differences between barefoot and shod running, through a literature review. This discussion is divided in four question-guided sections. Running kinematics is discussed in the first two sections; while the running kinetics and its neuromuscular aspects are discussed in sections 3 and 4 , respectively. 
Table 2 . Number of participants, age group and level of running practice in the studies included in the review (continues).

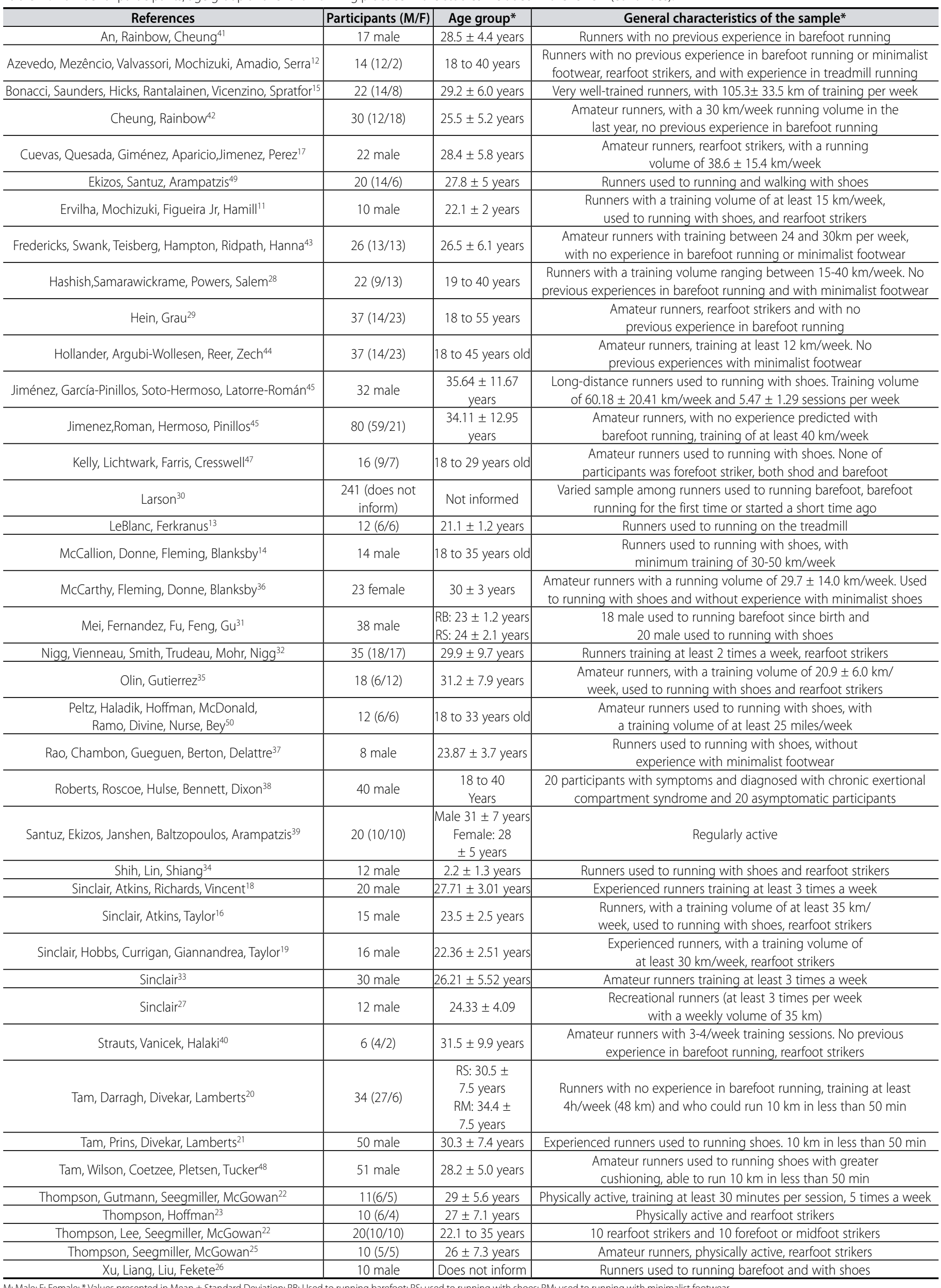

M: Male; F: Female; * Values presented in Mean \pm Standard Deviation; RB: Used to running barefoot; RS: used to running with shoes; RM: used to running with minimalist footwear. 


\section{How different are the motion patterns in shod and barefoot running?}

There are different ways to define the running pattern. For example, by the foot strike (forefoot, midfoot or rearfoot) pattern, or by the running strategy using stride length or cadence. In this review, we found stride length and cadence differs between shod and barefoot running. Stride length is shorter in barefoot running, and consequently, cadence is faster. Hall et al.? has described similar results.

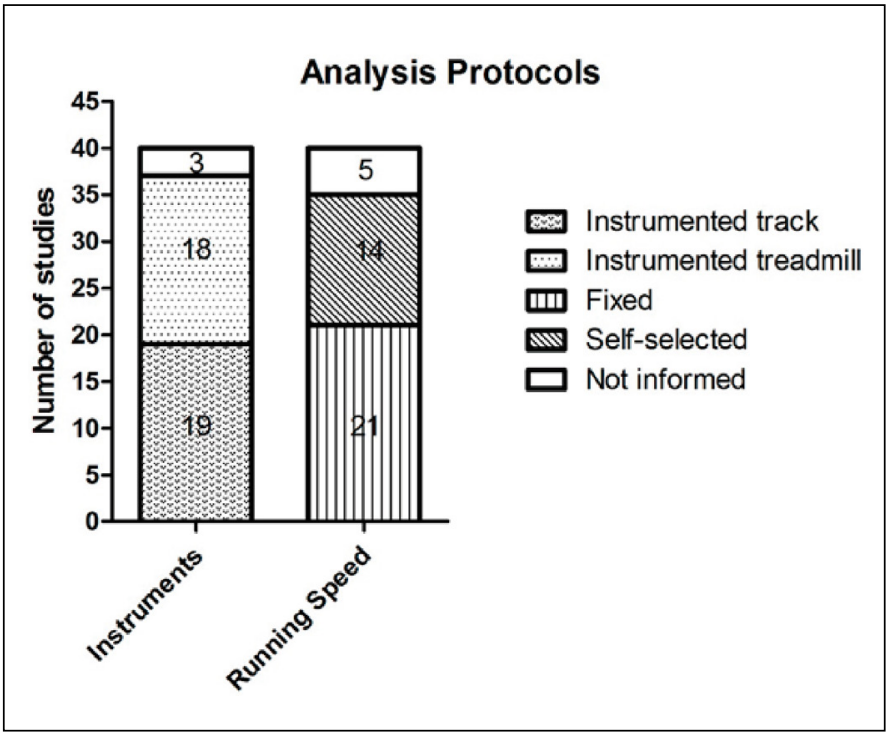

Figure 2. Number of studies according with the instruments and running speeds used in the analysis protocols.
The foot strike differs between shod and barefoot running. Barefoot running is associated to mid and forefoot strike patterns, while shod running is associated with rearfoot strike. Stance time in mid/forefoot strike is shorter. Faster some people run, more typical such strike patterns are, ${ }^{51,52}$ suggesting subgroups, that is, some runners change, while others do not, their foot strike pattern when they run faster. Besides, barefoot running might provide more sensory information during foot strike. ${ }^{5}$ Shoes might reduce the foot sensory information during the stance phase..$^{33}$ In addition, the first attempts to run barefoot are usually associated to higher GRF, leading to change foot strike pattern. Stride length is shorter in barefoot running, and it depends on swing phase. A shorter swing phase can be associated with a lower GRF and a shock attenuation strategy. ${ }^{54}$

Barefoot running has a faster cadence. This is a consequence of kinematic changes during the stance phase..$^{5}$ In the barefoot condition, De Wit, Clercq and Aerts ${ }^{55}$ suggest the leg stiffness is higher, inducing higher cadence. The leg stiffness is affected by how the GRF vector is oriented to ankle, knee and hip joints. ${ }^{4}$ Cadence is associated with swing leg properties as an inverted pendulum and stance time also influences it. Stance time shorts when foot strike is not with the rearfoot, and, for barefoot condition when foot strike is mid/forefoot strike. Differences on spatiotempral parameters, such as cadence, ${ }^{21,22,24,25,28,45}$ are evident even when the speed in both conditions (shod and barefoot running) is similar.

\section{How does footwear affect joint kinematics in running?}

Comparing running with and without shoes, the lower limb joint kinematics is different. We highlight differences in the ankle, knee and hip. Hall et al.' showed limited evidence for the ankle and moderate

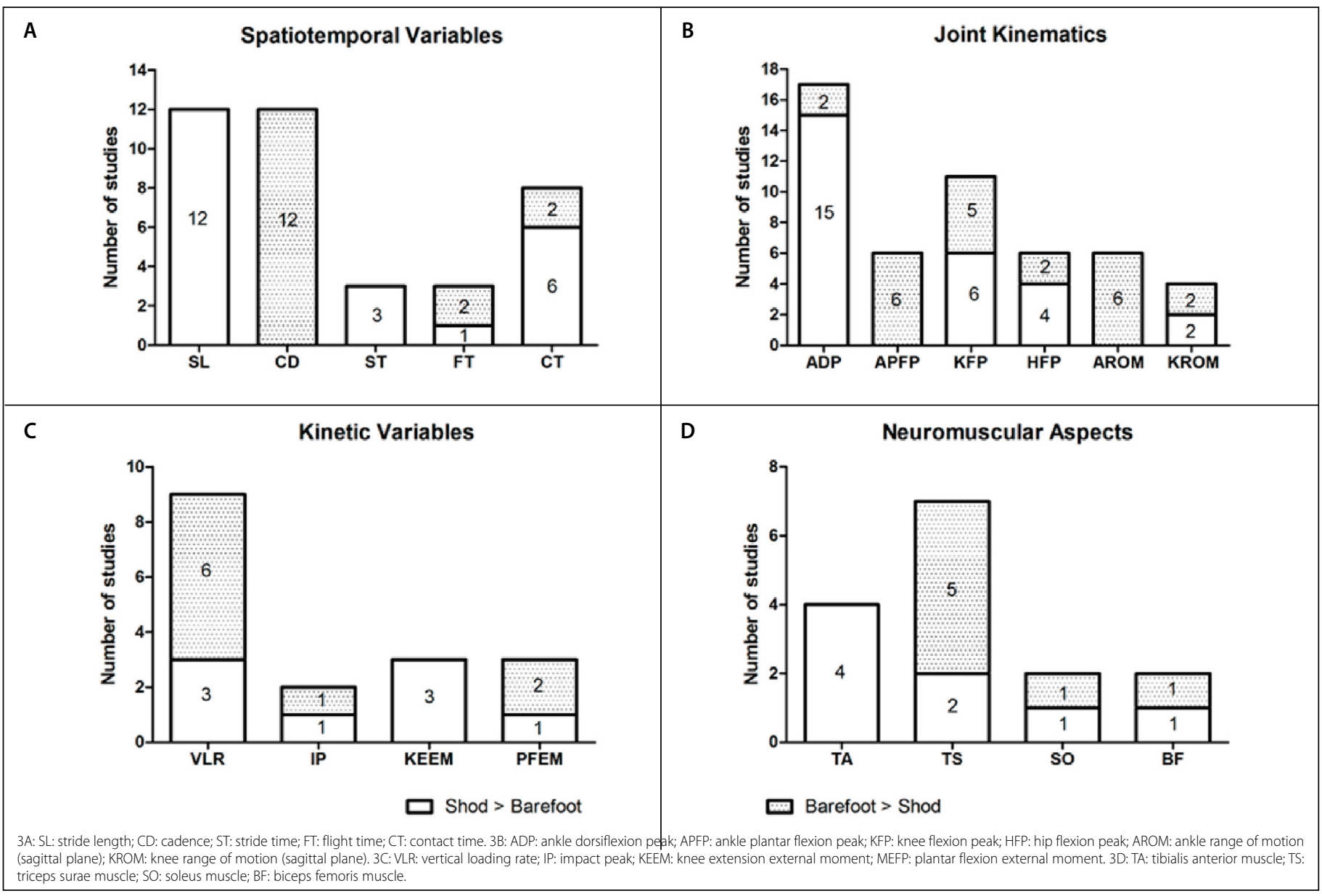

Figure 3. Number of studies that showed significant differences in the comparison of the spatiotemporal parameters (A), joint kinematics (B), kinetic variables (C) and neuromuscular aspects (D) between shod and barefoot running. 
evidence for the knee. In addition, we have found results that indicate changes in hip movements in running.

During barefoot running, ankle dorsiflexion decreases, plantar flexion increases, and the foot strikes the ground in ankle plantar flexion. When running with a rearfoot pattern, dorsiflexion occurs at the foot strike. Hall et al. ${ }^{7}$ showed limited evidence suggesting greater eversion in barefoot running. Ankle ROM is larger during stance phase in barefoot running; however, for the initial contact and impulsion, such ROM is larger in shod running. ${ }^{40}$ Strauts et al. ${ }^{40}$ found the runners used rearfoot strike in both shod and barefoot running. This result may be related to a lower ankle ROM in the barefoot condition compared with studies in which foot strike patterns varied among forefoot, midfoot and rearfoot patterns.

During stance phase, knee flexion is higher in barefoot running. Such knee flexion can reduce the vertical GRF and decrease injury risk. ${ }^{56}$ For barefoot runners with forefoot strike pattern, the knee ROM is shorter. Thus, barefoot running increases the maximum knee flexion, but decreases its ROM.

Barefoot running changes hip joint kinematics, and hip flexion ROM is lower during stance phase. ${ }^{40}$ Strauts et al. ${ }^{40}$ suggested changes in hip and pelvis angles are coordinated with ankle joint movements. Muscle strength, muscle activation patterns, anthropometry, joint mobility and muscle length also affect hip, pelvis and trunk kinematics during running. ${ }^{33}$

\section{Does GRF decrease in barefoot running?}

Kinetic gait analysis is mostly GRF-based and well-established in gait analysis. The GRF decreases with shorter stride length.22 The shorter the stride length, closer is the initial foot contact to the vertical projection of the center of mass, whereas the knee and hip flexion peaks decrease. ${ }^{57}$ The first peak of the vertical GRF is lower in barefoot condition and associated with shorter stride length. ${ }^{34,47}$ Such peak decrease may be related to GRF spectral change ${ }_{i}^{58}$ while forefoot strike pattern has more power spectrum up to $10 \mathrm{~Hz}$, rearfoot strike pattern has more power spectrum above $10 \mathrm{~Hz}$, including higher GRF frequency content like GRF transient. This implies the smallest first GRF peak is not due to barefoot running, but due to the forefoot strike pattern.

Runners used to run barefoot and with the forefoot strike pattern have only propulsion GRF peak, while runners used to run with shoes showed the impact and propulsion GRF peaks. ${ }^{22}$ Running with and without shoes produce similar GRF. ${ }^{40}$ The impact peak is three times lower in runners used to run barefoot with forefoot strike compared with runners used to run with rearfoot strike. ${ }^{9}$ But, the GRF peak was higher in barefoot condition with rearfoot strike compared to shod condition. ${ }^{40}$ Lieberman et al. ${ }^{9}$ showed the GRF transient occurs during rearfoot strike pattern and it increases in barefoot condition compared with the shod condition.

The loading rate describes how fast GRF was applied during foot strike. In Hall et al., ${ }^{7}$ the loading rate changes according to the foot strike pattern in barefoot running. In barefoot running, the forefoot strike reduces the loading rate and the rearfoot strike increases it. ${ }^{28,34,41,42}$ For the rearfoot strike pattern, the loading rate is higher without shoes than running with shoes; ${ }^{28,31,34,47,48}$ but one study ${ }^{48}$ found no difference between these two conditions. The loading rate is a high frequency GRF component, ${ }^{59}$ and the high frequency GRF content is associated with the foot strike pattern, ${ }^{58}$ and not necessarily due to the barefoot running.

There is little information about the moment patterns in running with and without shoes. Two studies ${ }^{30,33}$ have shown the knee extension moment was higher in shod running than in barefoot running, and a study ${ }^{25}$ showed no difference in ankle, knee and hip moments between running conditions. Hall et al. ${ }^{7}$ did not evaluate the joint moments. Regardless of the shoe condition, the GRF peak and joint moments are not different for a similar speed condition. ${ }^{20}$ For shod and barefoot running, joint moment increases are associated with larger stride length. For the sagittal plane, increasing the stride length 10\% longer augmented the knee and ankle peak moment, but no differences were found between running with and without shoes.2.

\section{Does running barefoot alter the muscle activation patterns?}

The lower limb muscle activity, joint kinematics and kinetics are associated. We are presenting a larger muscle set and their behavior during running with and without shoes, compared with Hall et al. ${ }^{7}$

The interaction between foot strike patterns and running with or without shoes can change the leg muscles activation patterns. The triceps surae muscle activation is associated to the foot strike pattern. The gastrocnemius lateralis and medialis muscles showed more activation in the barefoot condition with forefoot strike than with rearfoot strike in any shoes condition. 11,17,34,35,37 For the rearfoot strike, ${ }^{47}$ the soleus and gastrocnemius muscles showed a peak activity during the stance phase and greater activity at the end of the swing phase. Bonacci et al. ${ }^{15}$ showed that for the barefoot running, these muscles were more active during ankle plantar flexion. The increased ankle joint moment during forefoot strike is associated with greater soleus, gastrocnemius lateralis and gastrocnemius medialis muscle activation. Soleus, gastrocnemius lateralis and tibialis anterior muscles were less active during barefoot running. ${ }^{40}$

The tibialis anterior muscle activation occurs during the foot strike. This muscle was more active during running with shoes and rearfoot strike. ${ }^{17,34}$ This muscle is more active immediately before foot strike. Such pre-activation maintains the plantar flexion at the end of the swing phase and prepares the leg for impact. During impact, the tibialis anterior muscle should be relaxed to release the forefoot. ${ }^{60}$

The knee extensor/flexor muscle activations depend on the interaction between barefoot running and running phases. The activation levels of vastus medialis and biceps femoral muscles have decreased in barefoot running compared with shod running during foot strike and propulsion phases. ${ }^{40}$ In the stance phase, the biceps femoris and rectus femoris muscles showed no difference between footwear and barefoot conditions. ${ }^{34}$ Probably, such similarity was induced by not controlling the foot strike pattern previously, ${ }^{40}$ and biceps femoral activation might respond more to foot strike pattern than shoe condition.

In general, this literature review and Hall et al. ${ }^{7}$ have similar results. Hall et al. ${ }^{7}$ is a meta-analysis with 18 studies published from 1979 to 2013 . Our narrative review combines the results of 40 studies from 2013 to 2018. To include various biomechanical studies about running with and without shoes, we have decided not to do a meta-analysis. We believe the results we have summarized will support the current and growing discussions about running with or without shoes. Despite these different studies being described, many biomechanical aspects of running with and without shoes were similar between Hall et al. ${ }^{7}$ and our review. Our review is an update for this subject.

\section{CONCLUSION}

This literature review showed important differences in the biomechanics of running with and without shoes. Such differences should be understood and considered in the decision-making process between running with shoes or barefoot. Running barefoot might present lower impact forces, but still has a high loading rate and high triceps surae muscle activation. More studies about variables few explored, e.g. joint kinetics, should be carried out to enhance the understanding of running with and without shoes.

\section{FUNDING}

This study was partially financed by the Coordination of Superior Level Staff Improvement (CAPES), Brazil, Finance Code 001.

All authors declare no potential conflict of interest related to this article 
AUTHORS' CONTRIBUTIONS: Each author made significant individual contributions to this manuscript. VSJ and CKC: writing, database searches, analysis and interpretation of the data; ED: writing and revision of the work; LM and CR: critical review of the intellectual content of the work. All authors read and approved the final version of the article.

\section{REFERENCE}

1. USA R. Number of runners USA. 2017 [Acesso em: 22 jan 2019]. Disponível em: https://runningusa. org/RUSA/News/2018/U.S._Road_Race_Participation_Numbers_Hold_Steady_for_2017.aspx

2. Federação Paulista de Atletismo. Demonstrativo de corridas de rua nos últimos anos no Estado de São Paulo. 2016 [Acesso em 11 Jan 2019]. Disponível em: http://www.atletismofpa.org.br/ estatistica-2016.html

3. Van Gent RN, Siem D, Van Middeloop M, Van Os AG, Bierma-Zeinstra SMA, Koes BW. Incidence and determinants of lower extremity running injuries in long distance runners: A systematic review. Sport en Geneeskd. 2007:40(4):16-29.

4. Lohman EB, Balan Sackiriyas KS, Swen RW. A comparison of the spatiotemporal parameters, kinematics, and biomechanics between shod, unshod, and minimally supported running as compared to walking Phys Ther Sport. 2011;12(4):151-63.

5. Rothschild C. Running barefoot or in minimalist shoes: Evidence or conjecture? Strength Cond J, 2012;34(2):8-17.

6. Altman AR, Davis IS. Prospective comparison of running injuries between shod and barefoot runners. Br J Sports Med. 2016;50(8):476-80.

7. Hall JPL, Barton C, Jones PR, Morrissey D. The biomechanical differences between barefoot and shod distance running: A systematic review and preliminary meta-analysis. Sport Med. 2013;43(12):1335-53.

8. Robbins SE, Gouw GJ. Athetic footwear: unsafe due to perceptual illusions. Med Sci Sport Exerc.1991;23(2):217-24.

9. Lieberman DE, Venkadesan M, Werbel WA, Daoud AI, D'Andrea S, Davis IS, et al. Foot strike patterns and collision forces in habitually barefoot versus shod runners. Nature. 2010;463(7280):531-5.

10. Guisande TP, Amadio JC, Amadio AC, Mochizuki L. As forças transientes durante a marcha militar. Rev Bras Med do Esporte. 2013;19(6):390-3.

11. Ervilha UF, Mochizuki L, Figueira A, Hamill J. Are muscle activation patterns altered during shod and barefoot running with a forefoot footfall pattern?. J Sports Sci. 2017;35(17):1697-703.

12. Azevedo APS, Mezêncio B, Valvassori R, Mochizuki L, Amadio AC, Serrão JC. Does "transition shoe" promote an intermediate biomechanical condition compared to running in conventional shoe and in reduced protection condition?. Gait Posture. 2016;46:142-6.

13. LeBlanc M, Ferkranus H. Lower Extremity Joint Kinematics of Shod, Barefoot and Simulated Barefoot Treadmill Running. Int J Exerc Sci. 2018;11(1):717-29.

14. McCallion C, Donne B, Fleming N, Blanksby B. Acute differences in foot strike and spatiotemporal variables for shod, barefoot or minimalist male runners. J Sport Sci Med. 2014:13(2):280-6.

15. Bonacci J, Saunders PU, Hicks A, Rantalainen T, Vicenzino BT, Spratford W. Running in a minimalist and lightweight shoe is not the same as running barefoot: A biomechanical study. Br J Sports Med. 2013;47(6):387-92.

16. Sinclair J, Atkins S, Taylor PJ. The effects of barefoot and shod running on limb and joint stiffness characteristics in recreational runners. J Mot Behav. 2016;48(1):79-85.

17. Lucas-Cuevas AG, Priego Quesada Jl, Giménez JV, Aparicio I, Jimenez-Perez I, Pérez-Soriano P. Initiating running barefoot: Effects on muscle activation and impact accelerations in habitually rearfoot shod runners. Eur J Sport Sci. 2016;16(8):1145-52.

18. Sinclair J, Atkins S, Richards J, Vincent H. Modelling of Muscle Force Distributions during Barefoot and Shod Running. J Hum Kinet. 2015;47(1):9-17.

19. Sinclair J, Hobbs SJ, Currigan G, Giannandrea M, Taylor PJ. Tibiocalcaneal kinematics during barefoot and in barefootinspired shoes in comparison to conventional running footwear. Mov Spor Sci. 2014;1 (83):67-75.

20. Tam N, Darragh IAJ, Divekar NV. Lamberts RP. Habitual Minimalist Shod Running Biomechanics and the Acute Response to Running Barefoot. Int J Sports Med. 2017;38(10):770-5.

21. Tam N, Prins D, Divekar NV, Lamberts RP. Biomechanical analysis of gait waveform data: exploring differences between shod and barefoot running in habitually shod runners. Gait Posture. 2017;58:274-9.

22. Thompson MA, Gutmann A, Seegmiller J, McGowan CP. The effect of stride length on the dynamics of barefoot and shod running. J Biomech. 2014;47(11):2745-50.

23. Thompson MA, Hoffman KM. Superficial plantar cutaneous sensation does not trigger barefoot running adaptations. Gait Posture. 2017;57:305-9.

24. Thompson MA, Lee SS, Seegmiller J, McGowan CP. Kinematic and kinetic comparison of barefoot and shod running in mid/forefoot and rearfoot strike runners. Gait Posture. 2015;41(4):957-9.

25. Thompson M, Seegmiller J, McGowan CP. Impact Accelerations of Barefoot and Shod Running. Int J Sports Med. 2016;37(5):364-8

26. Xu SD, Liang ZQ, Liu YW, Fekete G. Biomechanical Performance of Habitually Barefoot and Shod Runners during Barefoot Jogging and Running. Biomimetics. 2018;38:1-10.

27. Sinclair J. Effects of barefoot and shod running on lower extremity joint loading, a musculoskeletal simulation study. Sport Sci Health. 2018;14:1-10.

28. Hashish R, Samarawickrame SD, Powers CM, Salem GJ. Lower limb dynamics vary in shod runners who acutely transition to barefoot running. J Biomech. 2016;49(2):284-8.

29. Hein T, Grau S. Can minimal running shoes imitate barefoot heel-toe running patterns? Acomparison of lower leg kinematics. J Sport Heal Sci. 2014;3(2):67-73.

30. Larson P. Comparison of foot strike patterns of barefoot and minimally shod runners in a recreational road race. J Sport Heal Sci. 2014;3(2):137-42.
31. Mei Q, Fernandez J, FuW, Feng N, Gu Y. A comparative biomechanical analysis of habitually unshod and shod runners based on a foot morphological difference. Hum Mov Sci. 2015;42:38-53.

32.Nigg BM, Vienneau J, Smith AC, Trudeau MB, Mohr M, Nigg SR. The preferred movement path paradigm: Influence of running shoes on joint movement. Med Sci Sports Exerc 2017;49(8):1641-8.

33. Sinclair J. The Effects of Barefoot and Barefoot Inspired Footwear Running on Tibiofemoral Kinetics. Hum Mov. 2016;17(3):176-80.

34. Shih Y, Lin KL, Shiang TY. Is the foot striking pattern more important than barefoot or shod conditions in running? Gait Posture. 2013;38(3):490-4.

35. Olin ED, Gutierrez GM. EMG and tibial shock upon the first attempt at barefoot running. Hum Mov Sci. 2013;32(2):343-52

36. McCarthy C, Fleming N, Donne B, Blanksby B. Barefoot running and hip kinematics: Good news for the knee? Med Sci Sports Exerc. 2015;47(5):1009-16.

37. Rao G, Chambon N, Guéguen N, Berton E, Delattre N. Does wearing shoes affect your biomechanical efficiency? J Biomech. 2015:48(3):413-7.

38. Roberts A, Roscoe D, Hulse D, Bennett AN, Dixon S. Plantar pressure differences between cases with symptoms of clinically diagnosed chronic exertional compartment syndrome and asymptomatic controls. Clin Biomech. 2017;50:27-31.

39. Santuz A, Ekizos A, Janshen L, Baltzopoulos V, Arampatzis A. The Influence of Footwear on the Modular Organization of Running. Front Physiol. 2017;8:958

40. Strauts J, Vanicek N, Halaki M. Acute changes in kinematic and muscle activity patterns in habitually shod rearfoot strikers while running barefoot. J Sports Sci. 2016;34(1):75-87.

41. An W, Rainbow MJ, Cheung RTH. Impacts of Surface Inclination on the Vertical Loading Rates and Landing Pattern in Novice Barefoot Runners. Biomed Res Int. 2015;101(Suppl 1):1-7.

42. Cheung RTH, Rainbow MJ. Landing pattern and vertical loading rates during first attempt of barefoot running in habitual shod runners. Hum Mov Sci. 2014;34(1):120-7.

43. Fredericks W, Swank S, Teisberg M, Hampton B, Ridpath L, Hanna JB. Lower extremity biomechanical relationships with different speeds in traditional, minimalist, and barefoot footwear. J Sport Sci Med 2015;14(2):276-83.

44. Hollander K, Argubi-Wollesen A, Reer R, Zech A. Comparison of minimalist footwear strategies for simulating barefoot running: A randomized crossover study. PLoS One. 2015;10(5):1-11.

45. Muñoz-Jimenez M, Latorre-Román PA, Soto-Hermoso VM, García-Pinillos F. Influence of shod/unshod condition and running speed on foot-strike patterns, inversion/eversion, and vertical foot rotation in endurance runners. J Sports Sci. 2015;33(19):2035-42

46. Jiménez MM, García-Pinillos F, Soto-Hermoso VM, Latorre-Román PA. Can running kinetics be modified using a barefoot training program? Apunt Med I'Esport. 2018;53(199):98-104.

47. Kelly LA, Lichtwark GA, Farris DJ, Cresswell A. Shoes alter the spring-like function of the human foot during running. J R Soc Interface. 2016;13(119):20160174.

48. Tam N, Astephen Wilson JL, Coetzee DR, van Pletsen L, Tucker R. Loading rate increases during barefoot running in habitually shod runners: Individual responses to an unfamiliar condition. Gait Posture. 2016;46:47-52.

49. Ekizos A, Santuz A, Arampatzis A. Transition from shod to barefoot alters dynamic stability during running. Gait Posture. 2017;56:31-6.

50. Peltz CD, Haladik JA, Hoffman SE, McDonald M, Ramo NL, Divine G, et al. Effects of footwear on three dimensional tibiotalar and subtalar joint motion during running. J Biomech. 2014;47(11):2647-53.

51. Breine B, Malcolm P, Galle S, Fiers P, Frederick EC, De Clercq D. Running speed-induced changes in foot contact pattern influence impact loading rate. Eur J Sport Sci. 2018;19(5)1-10.

52. Forrester SE, Townend J. The effect of running velocity on footstrike angle - A curve-clustering approach. Gait Posture. 2015;41(1):26-32.

53. Rixe JA, Gallo RA, Silvis ML. The barefoot debate: Can minimalist shoes reduce running-related injuries? Curr Sports Med Rep. 2012;11(3):160-5.

54. Mercer JA, Devita P, Derrick TR, Bates BT. Individual effects of stride length and frequency on shock attenuation during running. Med Sci Sports Exerc. 2003;35(2):307-13.

55. De Wit B, De Clercq D, Aerts P. Biomechanical analysis of the stance phase during barefoot and shod running. J Biomech. 2000;33(3):269-78.

56. DerrickTR. The Effects of Knee Contact Angle on Impact Forces and Accelerations. Med Sci Sport Exerc 2004:36(5)832-7.

57. Heiderscheit BC, Chumanov ES, Michalski MP, Wille CM, Ryan MB. Effects of step rate manipulation on joint mechanics during running. NIH Public Access. 2012;43(2):296-302.

58. Hamill J, Gruber AH. Is changing footstrike pattern beneficial to runners? J Sport Heal Sci. 2017;6(2):146-53.

59. Gruber AH, Edwards WB, Hamill J, Derrick TR, Boyer KA. A comparison of the ground reaction force frequency content during rearfoot and non-rearfoot running patterns. Gait Posture. 2017;56:54-9.

60. Von Tscharner V, Goepfert B, Nigg BM. Changes in EMG signals for the muscle tibialis anterior while running barefoot or with shoes resolved by non-linearly scaled wavelets. J Biomech. 2003;36(8):1169-76. 